\title{
Corrodibility and Adherence of Reinforced Concrete Rebars Electroplated with Zinc and Zinc-Nickel Alloys
}

\author{
Felipe Araujo Cedrim ${ }^{a}$,Vitor Laytynher Santos de Almeida ${ }^{a}$ Carlos Alberto Caldas de Souza ${ }^{a}$, \\ Paulo Roberto Lopes Lima ${ }^{b}{ }^{\mathbb{D}}$, Michele David de Jesus $^{a} \mathbb{D}^{\mathbb{B}}$, Daniel Véras Ribeiro ${ }^{a} \mathbb{C}_{\mathbb{D}}$ \\ ${ }^{a}$ Departamento de Ciência e Tecnologia dos Materiais, Escola Politécnica, Universidade Federal da Bahia, \\ Rua Prof. Aristides Novis, 2, CEP: 40210-630, Salvador, BA, Brasil \\ ${ }^{b}$ Departamento de Tecnologia, Universidade Estadual de Feira de Santana, Av. Transnordestina, \\ 44036-900, Feira de Santana, BA, Brasil
}

Received: December 19, 2018; Revised: March 11, 2019; Accepted: May 22, 2019

\begin{abstract}
Reinforced concrete is the main structural material used in the world in the construction of bridges, roads and commercial and residential buildings. One effective method for preventing corrosion of steel reinforcement is the application of galvanic coatings to the reinforcement itself. The present study evaluated the performance of three groups of reinforcing steel bars (black steel, used as a reference and rebars electroplated with Zinc and Zinc-Nickel alloys) to corrosion and adherence to the concrete matrix. For the analysis of corrosion, the specimens were subjected to two different accelerated corrosion tests: salt spray exposure and wet and dry semi-cycles. The corrosion potential was measured for the qualitative monitoring of the corrosion process and the corrosion rate was estimated. In order to evaluate the steel-concrete adherence, the pullout test was used, in accordance with RILEM-CEB-FIP. The results showed that Zinc and Zinc-Nickel coatings increased the durability of the reinforcing bars and the accelerated corrosion test of wetting and drying cycles proved to be more aggressive compared to the salt spray method to evaluate the corrosion process in the reinforced concrete specimens. Additionally, galvanized reinforcement reduced adherence to the concrete matrix.
\end{abstract}

Keywords: electroplating, rebar, corrosion potential, reinforced concrete, adherence.

\section{Introduction}

Reinforced concrete is the main structural material used in the world in the construction of bridges, roads and commercial and residential buildings. However, corrosive processes in reinforcement bars have resulted in premature deterioration of reinforced concrete structures and generated high costs for maintenance and recovery, especially in countries with urban centers located close to the sea.

According to the U.S. Federal Highway Administration (FHWA), in 2002, the estimated annual direct cost of corrosion in the United States was about $\$ 276$ billion, approximately $3.1 \%$ of the US Gross Domestic Product (GDP). Aging infrastructure (buildings, bridges, roads, plants, pipelines, tanks, and other key elements) is a serious problem with a cost of $\$ 22.6$ billion ${ }^{1}$. In the European Union, 30 to $50 \%$ of the annual cost of infrastructure maintenance is spent on corrosion-related issues ${ }^{2}$. In Brazil this cost exceeds 3 billion dollars per year ${ }^{3}$. This indicates that, in addition to technical issues, the development and use of methods that can maximize the service life of concrete structures is of fundamental economic importance for any country.

*e-mail: verasribeiro@hotmail.com.
Good practices, such as the correct positioning of the reinforcing bars in the moulds and the assuring of correct pouring, good concrete quality, compaction and curing of the concrete structures, would be enough to ease corrosion problems. Knowing the exposure environments is also very important. Additional measures of corrosion protection are available to the engineer and builder ${ }^{4}$. These include, but are not limited to:

- $\quad$ the use of membrane-type coatings applied to the surface of concrete

- $\quad$ the painting of concrete

- $\quad$ the impregnation of concrete with materials designed to reduce its permeability

- the addition of corrosion inhibitors to the concrete

- $\quad$ the use of corrosion-resisting materials (e.g. stainless steels or polymeric rebars ${ }^{5}$ ) as a replacement for conventional steel reinforcement

- cathodic protection of the reinforcement; and/or

- the application of galvanic coatings to the reinforcement itself.

The application of galvanic coatings to the reinforcing bars has a special place. Zinc ( $\mathrm{Zn})$ is the most frequently used metal in these coatings ${ }^{6}$, mainly because of its ability to create a dense and adherent protective film on the bar surface, causing the corrosion rates to decrease compared to those observed in ferrous materials. 
In addition to creating a barrier between the steel and the environment, zinc also can galvanically protect the steel. If the coating is damaged and the underlying steel exposed to the environment, zinc (being anodic to iron) will preferentially corrode and sacrificially protect the exposed steel against the corrosion process. In this type of corrosion protection, broadly known as cathodic protection, the base metal becomes the cathode in the corrosion cell and the coating metal the anode ${ }^{6}$.

Zinc has a number of characteristics that make it well suited for use as a coating for protecting rebars from corrosion. The excellent field performance of zinc coatings is due to its ability to form dense, adherent corrosion product films and a subsequent rate of corrosion considerably below that of ferrous materials, some 10-100 times slower, depending on the atmosphere ${ }^{7}$.

Zinc is an amphoteric metal, i.e. in solution reacts with both strong acidic and strong bases, the attack being most severe below pH 6 and above $\mathrm{pH}$ 13. Between these values, the rate of attack is very slow due to the formation of protective layers on the zinc surface ${ }^{8}$. Zinc in concrete is passivated for $\mathrm{pH}$ values between about 8 and 12.5 due to the formation of a protective surface film of corrosion that is relatively insoluble below $\mathrm{pH} 12.5$. Zinc reacts quite vigorously with wet concrete, but this reaction effectively ceases once the concrete has hardened. The result of these reactions is the formation of a barrier layer of calcium hydroxyzincate accompanied by the evolution of hydrogen ${ }^{8}$.

In ordinary concrete, uncoated steel depassivates once the $\mathrm{pH}$ level drops below about 11.5, though in chloridecontaminated concrete this depassivation occurs at higher $\mathrm{pH}$ levels. In contrast, zinc-coated steel in concrete remains passivated to $\mathrm{pH}$ levels of about 9.5 thereby offering substantial protection against the effects of carbonation of concrete. Zinc-coated reinforcement can also withstand exposure to chloride ion concentrations several times higher than that which causes corrosion of rebars ${ }^{9}$.

It is also common to add other components to the Zinc coating, such as cobalt $(\mathrm{Co})$, iron $(\mathrm{Fe})$ and nickel $(\mathrm{Ni})$, forming the alloys $\mathrm{Zn}-\mathrm{Co}, \mathrm{Zn}-\mathrm{Fe}$ and $\mathrm{Zn}-\mathrm{Ni}$, which present better properties when compared to the pure Zinc coatings. In this context, the compounds based in $\mathrm{Zn}-\mathrm{Ni}$ are attracting more interest regarding protection against corrosion due to its superior chemical and mechanical properties ${ }^{10}$.

There are two main methods of producing the zinc protective layer: hot-dip galvanizing and electroplating. Hot-dip galvanizing involves the immersion of cleaned steel in a bath of molten zinc at about $450^{\circ} \mathrm{C}$ allowing a metallurgical reaction to occur between the steel and the zinc. This reaction produces a coating on the steel made up of a series of iron-zinc alloy layers, which grow from the steel/zinc interface with a layer of essentially pure zinc on the outer surface ${ }^{35}$. Electroplating is a process that uses an electric current to reduce dissolved metal cations so that they form a thin coherent metal coating on an electrode.
The term is also used for electrical oxidation of anions on to a solid substrate ${ }^{11}$.

Hot-dip galvanizing deposits a thick, robust layer of zinc iron alloys on the surface of a steel rebar. Electroplating produces a layer that is extremely thin and relatively free of pores, avoiding material waste ${ }^{12-14}$. The thickness of the coating is influenced by some factors, for instance the current density, the salt concentration, the bath temperature, the presence of additives and the nature of the base metal ${ }^{15}$. Furthermore, the electroplating method does not generate intermetallic alloys like the hot dip galvanizing method, providing a more homogenous and thin coating that will not affect mechanic properties of its substrate ${ }^{16}$.

Among the various electrochemical techniques used to monitor the corrosive process in reinforced concrete, corrosion potential measurements are the most commonly used. Monitoring of the corrosion potential enables changes in the electrochemical corrosion process to be recorded, which can be of interest in monitoring structures ${ }^{6}$. The corrosion potential of the rebars is a mixed potential, resulting from the combination of the kinetics of two processes: (1) metal oxidation, and (2) reduction of dissolved oxygen, without providing quantitative information, i.e., information about the reinforcement corrosion rate cannot be obtained ${ }^{17}$. Thus, the rebar corrosion potential provides a rough indication of a rebar corrosion situation or a rebar passive state.

The ASTM C-876/91 standard presents a correlation between corrosion potential ranges and the probability of the occurrence of corrosion as a criterion for corrosion evaluation, taking as reference a copper/copper sulfate electrode $\left(\mathrm{Cu} / \mathrm{CuSO}_{4}, \mathrm{Cu}^{2+}\right)$.

Because galvanized steel has a ferritic base which is magnetic, a coating of zinc will not upset the cover. However, it will affect the interpretation of electrochemical test results because the magnitude of the potential will be different between steel and zinc ${ }^{10}$. Once corrosion initiates, the potential of zinc is some $400 \mathrm{mV}$ more negative than that of black (ordinary) steel and therefore it is important to understand how to interpret reference electrode potentials where the criteria suggested in ASTM C876 for the corrosion of black steel simply does not apply. It is important to note that the potential of the zinc and zinc alloys in the coating rises steadily from about $-1100 \mathrm{mV}$ (vs SCE) to about -600 $\mathrm{mV}$ as the dissolution of the coating proceeds and the more iron-rich alloy layers in the coating are exposed ${ }^{10}$.

According to Sherine et al. ${ }^{18}$ and Panek et al. ${ }^{19}$, when black steel is electroplated with zinc, lower values of corrosion potential are associated with a high probability of corrosion. These values are equal to $-274 \mathrm{mV}$ for ordinary rebars, $-953 \mathrm{mV}$ for rebars electroplated with zinc-nickel and $-1043 \mathrm{mV}$ for rebars electroplated with zinc, to saturated calomel electrode (SCE), see Table 1. 
Table 1. Probability of rebars corrosion activity as a function of ranges of corrosion potential for ordinary (black steel) rebars and rebars electroplated with zinc and zinc-nickel alloys (reference: saturated calomel electrode, SCE)

\begin{tabular}{ccc}
\hline \multirow{2}{*}{ Rebar Surface } & \multicolumn{2}{c}{ Probability of Rebar Corrosion Activity } \\
\cline { 2 - 3 } & "Passivation" $(<10 \%)$ & Corrosion $(>90 \%)$ \\
\hline Black Steel & $>-0.124 \mathrm{~V}$ & $<-0.274 \mathrm{~V}$ \\
Electroplated with Zn & $>-0.650 \mathrm{~V}$ & $<-1.043 \mathrm{~V}$ \\
Electroplated with Zn-Ni $(5 \%)$ & $>-0.550 \mathrm{~V}$ & $<-0.953 \mathrm{~V}$ \\
\hline
\end{tabular}

In reinforced concrete, effective bond between reinforcing bars and concrete is vital for the full development of composite action. Hence, the bond of reinforcing bars plays an important role in the structural behaviour of reinforced concrete ${ }^{20}$. The bond strength between the concrete and reinforcement bar is determined by three main components: shear stresses due to adhesion along the bar surface, the bearing stresses against the faces of rebars (mechanical interlock), and the friction between the rebars and the surrounding concrete. Despite the fact that the principal contribution to bond strength comes from the mechanical interlock, the chemical adhesion mechanism occurs firstly and, after loading, prevents slip that will only happen after the adhesion is destroyed.

The adhesion bond is the result of the chemical reaction between the reinforcement and the hydrated cement compounds within the interstitial transition zone to form a true chemical bond. The nature of the bonding is dependent on the atomic arrangement, molecular conformation, morphological properties and chemical constitution of the reinforcement and concrete and can be attributed to mechanisms including adsorption and wetting electrostatic attraction, chemical bond, reaction bonding, and exchange reaction bonding ${ }^{21}$.

Initially, the corrosion generates an increase in the adherence between rebars and concrete due to the increase in the surface roughness. However, this increase in adhesion occurs only initially because with a higher formation of oxides there is a loss of adherence, reducing the resistant capacity of the concrete ${ }^{22}$. The bond between the concrete and the reinforcement is essential for the full capacity of the reinforcement to be developed and the successful functioning of a reinforced concrete system.

Regarding the galvanized rebars, Cheng et al. ${ }^{23}$ argue that due to the low volumetric variation in the zinc corrosion products, there is no significant decrease in the steel-concrete bond during the corrosive process. However, some research indicates that the adherence reduces due to the formation of hydrogen gas when zinc is in contact with fresh concrete ${ }^{24}$.

In the present study, the influence of the zinc and zincnickel electroplating galvanization in the corrodibility and adherence of the reinforcing concrete was evaluated. The reinforced concrete specimens were subjected to two accelerated corrosion tests (wet and dry cycles and continuous salt fog), and the corrosion potential was measured. The bond characteristics of electroplated rebars in reinforced concrete have also been studied. Pullout tests were conducted on rebars embedded in the concrete.

\section{Materials and Methods}

\subsection{Materials}

The concrete was produced with Brazilian Portland cement (CPII Z-32, according to the Brazilian NBR 11578 standard), which is equivalent to the ASTM C 596 standard (Pozzolan-modified Portland cement). This cement contains pozzolan and is one of the cements most widely used in the state of Bahia, Brazil. The coarse aggregate was dense crushed granite stone and the fine aggregate was natural siliceous sand commercially available in Salvador, Bahia, Brazil.

Steel bars CA-50 class, according to Brazilian standards, $10.0 \mathrm{~mm}$ diameter, were used (C content between 0.3 and $0.5 \mathrm{wt} . \%$ ), with yield stress greater than $500 \mathrm{MPa}$ and a tensile strength of about $560 \mathrm{MPa}$. These steel bars are manufactured by the process of hot rolling without subsequent cold work.

\subsection{Methods}

\subsubsection{Characterization of the raw materials and concrete dosage}

Physical parameters of the materials such as the specific surface area (estimated by BET, using a Micromeritics Gemini 2370 V1.02 surface area analyzer), particle-size distribution (Mastersizer 2000) and specific gravity (Micromeritics Accupyc 1330 V2.01 helium pycnometer) were determined.

The concrete mix proportion was 1.0 (Portland cement): 1.5 (fine aggregate): 1.3 (coarse aggregate) and the water/ cement ratio was 0.5 . The mortar content was $75 \%$ and the cement consumption was $526 \mathrm{~kg} / \mathrm{m}^{3}$. After mixing, a vibrating table was used to ensure efficient compaction.

The corrosion potential was measured using prismatic specimens $\left(50 \times 70 \times 90 \mathrm{~mm}^{3}\right)$ into which steel bars (reference and electroplated) were inserted during molding. For the pull out tests, cylindrical specimens $(10 \mathrm{~cm}$ in diameter and $10 \mathrm{~cm}$ in height) were molded for each type of reinforcement (reference rebars with "surface oxidized", reference rebars without oxidation, zinc coated rebars and zinc nickel coated rebars).

All the specimens were unmolded $24 \mathrm{~h}$ after being cast and were cured for 28 days in a humid chamber ( $>95 \% \mathrm{HR}$ ). A minimum of 4 samples were tested for each measurement. 


\subsubsection{Zinc and Zinc Nickel Electroplating}

Before the electroplating process, the bars were cleaned with an iron brush and then were immersed in alcoholic aqueous solution to remove impurities and oxides adhering to the surface, assuring the efficiency of electroplating.

The $\mathrm{Zn}$ and $\mathrm{Zn}$-Ni alloys were deposited galvanostatically from a deposition solution, with concentrations according to Table 2. Electrodeposition was performed at $25^{\circ} \mathrm{C}$ in an aerated solution. All the experiments were performed in a single-compartment glass circular cell with a diameter of 7 $\mathrm{cm}$ and a capacity of $250 \mathrm{~mL}$. In the deposition experiments, a current source (HP, model 6140A) and a voltmeter-ammeter (ICEL, model ET 208-2B) were used (Figure 1). A bar of graphite, with a diameter of approximately $5 \mathrm{~mm}$ was used as an anode, and the steel rebars were used as the substrate for the electrodeposition. The cylindrical steel substrates were placed at $2 \mathrm{~cm}$ from the graphite anode in the central region of the cell. The galvanostatic depositions were conducted at a current density of $10 \mathrm{~mA} / \mathrm{cm}^{2}$ for $8-9 \mathrm{~min}$ to produce a $5 \mu \mathrm{m}$-thick deposit, which is a typical value in a galvanizing process line.

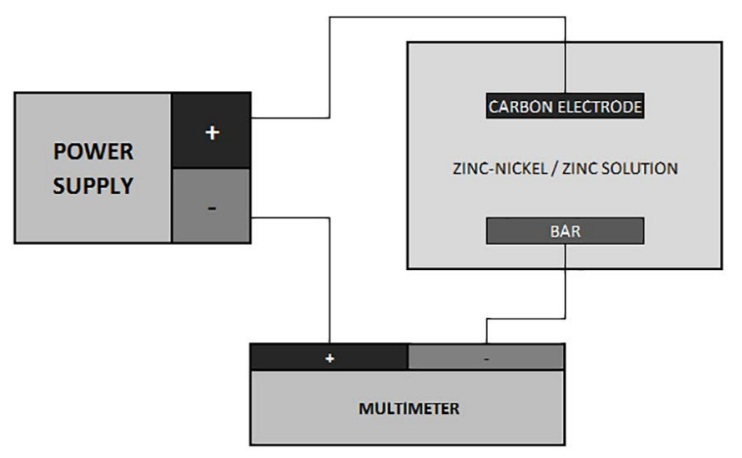

Figure 1. Methodology used for rebar electroplating process.

The mass of the deposit was estimated using the following equation $(1)^{25}$ :

$$
\mathrm{m}_{\mathrm{dep}}=\text { e.S. } \rho_{\mathrm{D}}
$$

, where $\mathrm{m}_{\mathrm{dep}}$ is the mass of the deposit, " $\mathrm{e}$ " is the thickness of the deposit $(5 \mu \mathrm{m}), \mathrm{S}$ is the deposition surface, and $\rho_{\mathrm{D}}$ is the density of deposit. The deposit density can be estimated using equations 2 or 3 :

$$
\begin{gathered}
\rho_{\mathrm{DZn}}=\rho_{Z n} \cdot \mathrm{C}_{\mathrm{Zn}}, \mathrm{C}_{Z n}=1.0 \\
\rho_{\mathrm{D} \mathrm{Zn}-\mathrm{Ni}}=\rho_{\mathrm{Zn}} \cdot \mathrm{C}_{\mathrm{Zn}}+\rho_{N i} \cdot \mathrm{C}_{\mathrm{Ni}}
\end{gathered}
$$

, where $\rho_{\mathrm{Zn}}$ is the density of $\mathrm{Zn}, \rho_{\mathrm{Ni}}$ is the density of the Ni. $\mathrm{C}_{\mathrm{Zn}}$ is the $\mathrm{Zn}$ mass fraction in the deposit and $\mathrm{C}_{\mathrm{Ni}}$ is the $\mathrm{Ni}$ mass fraction in the deposit, estimated from constituents proportion in solution.

According to the microphotographs shown in Figure 2, the obtained coatings had a uniform distribution of electrodeposited ions, creating a homogeneous layer, but with different morphologies for each case. The zinc coating exhibited a surface formed of flat randomly scattered grains of various sizes, and the Zinc-Nickel coating had spherical same sized grains distributed all over the surface, as reported in other research ${ }^{13,26}$.

\subsubsection{Corrosion potential measurement}

The reinforcement steel bars were weighed on an analytical balance with an accuracy of $0.01 \mathrm{~g}$. The area exposed to chloride attack (about $15.83 \mathrm{~cm}^{2}$ ) was then delimited with electrical insulating tape, as shown in Figure 3. The rebars were positioned so that the exposed area was located in the central region of the specimens, as illustrated in Figure 3d.

There was the possibility of crevice conditions due to the tape. However, after the test, no corrosion was detected on the sites that were covered by tape, indicating that the adhesion between the rebars and the tape was good.

The corrosion potential was verified from a chlorideactivated accelerated corrosion test. The electrochemical cell used for corrosion potential measurements was composed of a working electrode, the reinforcement steel rebars and the saturated calomel electrode (SCE) used as the reference electrode.

Before taking the measurements, the side of the specimen to be measured was pre-moistened with a wet sponge for one minute. A conductive solution containing $5 \mathrm{~mL}$ of neutral detergent to one liter of water, according to the ASTM C-876/91 standard

Table 2. Composition of the electrolyte solution used for zinc and zinc-nickel alloy electroplating.

\begin{tabular}{ccc}
\hline Component & Zinc Solution $(\mathrm{g} / \mathrm{L})$ & Zinc-10\%Nickel Solution $(\mathrm{g} / \mathrm{L})$ \\
\hline Potassium Choride & 208.0 & -- \\
Zinc Chloride & 19.6 & 38.5 \\
Nickel Chloride & --- & 34.5 \\
Ammonium Chloride & --- & 150.0 \\
Boric Acid & 20.0 & 20.0 \\
\hline
\end{tabular}




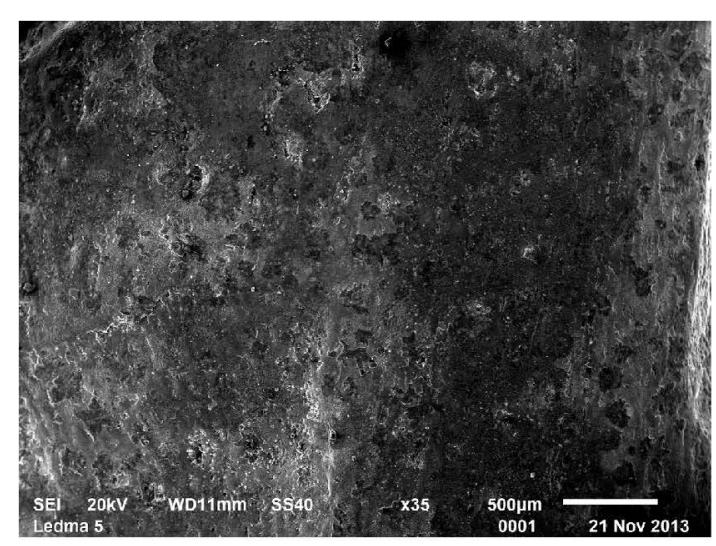

(a)

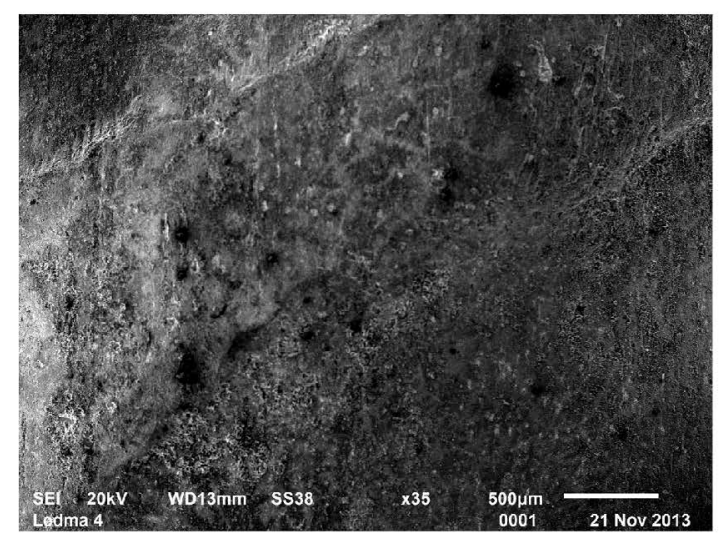

(c)

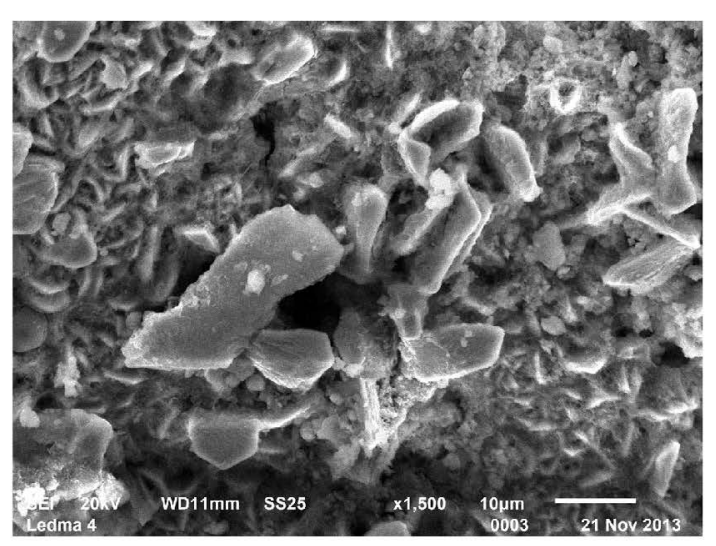

(b)

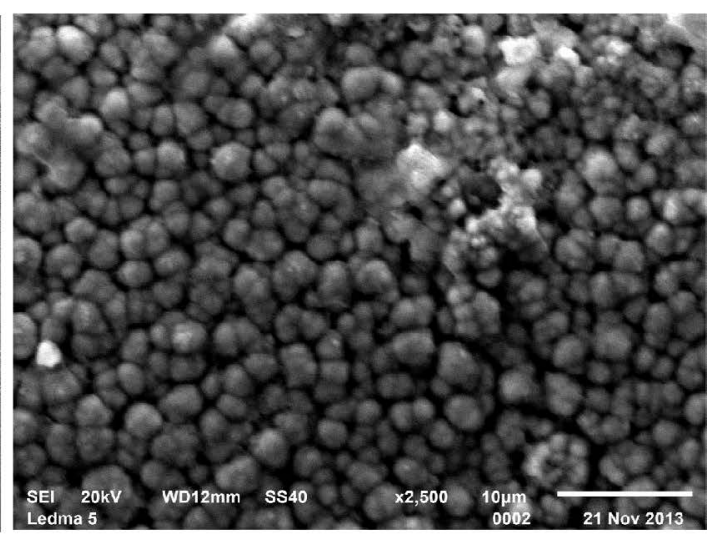

(d)

Figure 2. Morphology of film formed on rebar surface after the Zinc (A and B) and Zinc-Nickel (C and D) electroplating process.
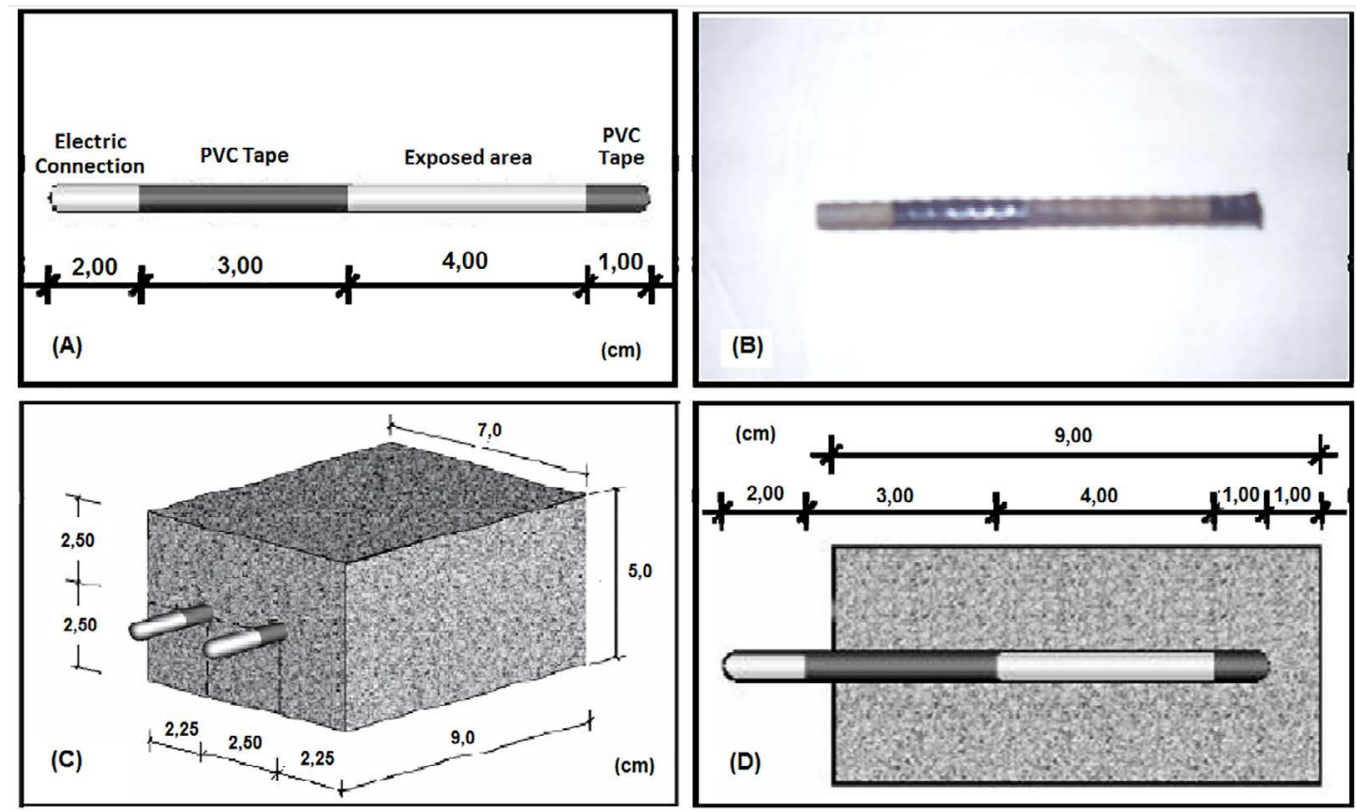

Figure 3. (A) and (B) Scheme of delimitation of the bars exposed area; (C) and (D) Position of bars inside the concrete specimen (RIBEIRO [6]). 
(Standard Test Method for Half-Cell Potentials of Uncoated Reinforcing Steel in Concrete) and an electrical conductivity of $0.15 ? 0.02 \mathrm{mS} / \mathrm{cm}$ were used. For the measurements, the reference electrode was positioned approximately at midspan over the rebar under analysis. The contact between the reference electrode and the specimen was aided with a damp sponge.

The corrosion test was started after 63 days, when the specimens showed a constant mass (1.0 gram of variation in two consecutive 24-hour readings) and when the measured corrosion potential indicated the formation of a passive film on the surface of the steel rebars $\left(\mathrm{E}_{\text {cor }}>-0.124 \mathrm{~V}\right.$ for reference rebars, $\mathrm{E}_{\text {corr }}>-0.650 \mathrm{~V}$ for zinc coated rebars and $\mathrm{E}_{\text {corr }}>-0.550 \mathrm{~V}$ for zinc-nickel coated rebars). These reference values correspond to a lower than $10 \%$ possibility of corrosion occurrence, according to the ASTM C 876/91 standard (for the saturated calomel electrode used in this work).

In other works ${ }^{27-30}$, it was necessary to define a specific age, or reference age, from which the procedures of the accelerated corrosion tests started. The authors of those studies associated the reference age to the stabilization of the cement hydration process and defined the ages of 63 days ${ }^{27,28}$ and 80 days ${ }^{29,30}$ as sufficient for the cement paste to acquire a relatively well developed physical structure and a significantly high degree of hydration.

After reaching the "safe potential," the specimens were subjected to two different accelerated corrosion tests: i) Salt spray exposure, using a Equilam SS600e chamber in accordance to ASTM B-117 (Standard Practice for Operating Salt Spray (Fog) Apparatus) with $\mathrm{NaCl}$ concentration of $5 \%$, pH between 6.5 and 7.2 and temperature of $35^{\circ} \mathrm{C}$; and ii) semi-cycles of partial immersion in $3 \mathrm{wt} \% \mathrm{NaCl}$ solution for two days and semi-cycles of drying in a ventilated oven at $50^{\circ} \mathrm{C}$ for five days. During the semi-cycle of partial immersion, the level of immersion solution was kept at half the height of the specimens. In such conditions, the chloride inflow occurs primarily by capillary absorption, since the specimens are first dried, and after the pores become saturated, the inflow occurs by diffusion, which is accelerated due to water evaporation through the exposed concrete. The corrosion potential $\left(\mathrm{E}_{\text {corr }}\right)$ was measured at the end of each semi-cycle.

According to MCCARTER apud SANTOS ${ }^{28}$, there is a relationship between the saturation level and the capillary suction forces in a porous material. Thus, when there is a dry and exposed region, these suction forces will be greater, pulling the solution faster into the concrete specimen.

At the end of each part of the cycle, the corrosion potential $\left(\mathrm{E}_{\text {corr }}\right)$ and the weight of the specimens were measured. The potential measurements were carried out to verify the condition of the rebars regarding its passivation/corrosion state, while the weighing was necessary to verify its saturation level, because if the water absorption after each wet half-cycle was different, the results of corrosion potential would be altered (dry concrete presents high electrical resistivity).
The active or passive state of corrosion was analyzed based on the corrosion potential (Ecorr), using the saturated calomel electrode (SCE) as reference. The test was concluded when two consecutive and full cycles resulted in corrosion potential values below the critical value.

After concluding the test, the rebars were extracted from the samples, cleaned according to the ASTM G-1/03 standard (Standard Practice for Preparing, Cleaning, and Evaluating Corrosion Test Specimens), and weighed to determine weight loss and to compare them with the initial value. Thus, the corrosion rate $(\mathrm{CR})$ can be calculated according to equation (4).

$$
C R=\frac{K \cdot W}{A \cdot T \cdot D}
$$

where $\mathrm{K}=$ constant (for $\mathrm{CR}\left(\mu \mathrm{m} /\right.$ year), $\mathrm{K}=8.76 \times 10^{7}$; for $\mathrm{CR}\left(\mathrm{g} / \mathrm{m}^{2}\right.$.year $\left.), \mathrm{K}=8.76 \times 10^{7} . \mathrm{D}\right) ; \mathrm{W}=$ weight loss (grams); $\mathrm{A}=$ exposed rebar area $\left(\mathrm{cm}^{2}\right) ; \mathrm{T}=$ exposure time (hours); $\mathrm{D}=$ steel rebar density (for CA-50 steel, $\mathrm{D}=7.85$ $\left.\mathrm{g} / \mathrm{cm}^{3}\right)$. In this study, $\mathrm{A}=15.83 \mathrm{~cm}^{2}$.

Metallic zinc reacts strongly with an aqueous solution of hydrochloric acid $(\mathrm{HCl})$ when it is concentrated, and when the metal is exposed for long periods of time. The result is the production of a large amount of hydrogen gas and the formation of zinc chloride $(\mathrm{ZnCl})$ in the solution. In the experiment, the zinc did not react because the $\mathrm{HCl}$ solution was diluted and the contact time between the solution and the rebars was only 60 seconds.

\subsubsection{Pull out test}

A photograph of the testing machine and test setup is presented in Figure 4. The samples were cast with the steel rebar of $10 \mathrm{~mm}$ in a vertical position. A ratio of 10:1 between concrete specimen diameter and rebar diameter was used. The steel bar was inserted into the concrete with bond length of $50 \mathrm{~mm}$ (Figure $4 \mathrm{a}$ ). The unbonded segments of the pull-out specimen were created by placing a plastic pipe $50 \mathrm{~mm}$ in length around the diameter of the steel bar. The setup for the pullout test is shown in Figure 4b, which is in accordance with RILEM-CEB-FIP ${ }^{31}$.

All pull out tests were carried out using a universal testing machine EMIC with a load capacity of $300 \mathrm{kN}$. From the pull out failure load measured by the testing machine, the bond strength was calculated as the failure load divided by the surface area of the bonded length of the reinforcing bar, as per the following equation $5^{20}$.

$$
\sigma=\mathrm{F} /(\pi . \mathrm{d} . \mathrm{l})
$$

where $\sigma=$ bond strength, $\mathrm{F}=$ failure load, $\mathrm{d}=$ diameter of the reinforcing bar, and $1=$ bonded length of the reinforcing bar. 


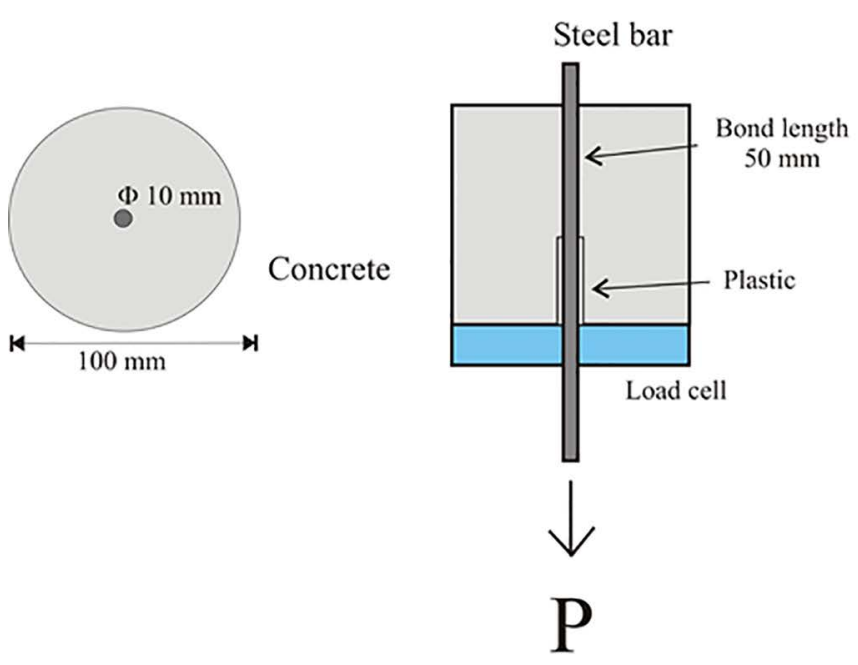

(A)

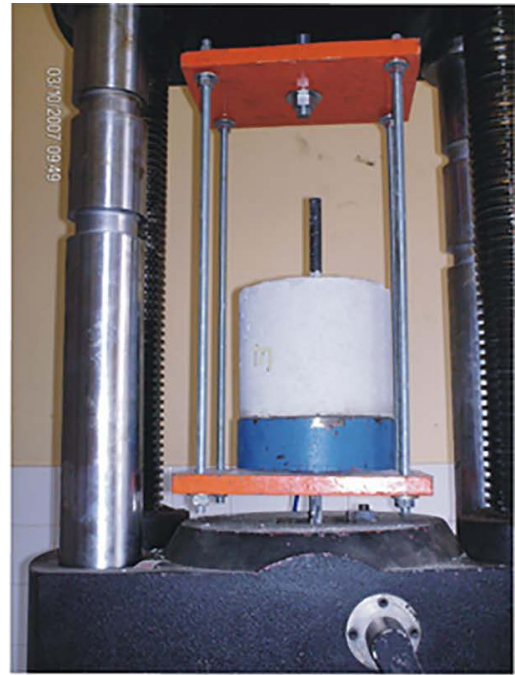

(B)

Figure 4. (A) Illustrative scheme and (B) setup of Pull out test.

\subsubsection{Scanning electron microscopy}

Scanning electron microscopy (SEM) was used to analyse the coatings of zinc and zinc-nickel on the rebars, verifying their microstructure and chemical composition. A Scanning Electron Microscope (SEM) Philips XL-30 and with EDX microprobe was used (tension of $25 \mathrm{KV}$ and work distance 11-13 mm).

\section{Results and Discussion}

\subsection{Materials characterization}

The Portland cement used here has a specific surface area of $0.425 \mathrm{~m}^{2} / \mathrm{g}$ and a specific gravity of $2.98 \mathrm{~kg} / \mathrm{dm}^{3}$. The sand has a specific surface area of $0.68 \mathrm{~m}^{2} / \mathrm{g}$, a specific gravity of $2.63 \mathrm{~kg} / \mathrm{dm}^{3}$, and fineness Modulus of 1.52 , classified as fine sand by the Brazilian NBR 7211 standard. The gravel has a specific gravity of $2.79 \mathrm{~kg} / \mathrm{dm}^{3}$ and a maximum dimension of $9.5 \mathrm{~mm}$. The particle size distribution is presented in Figure 5.

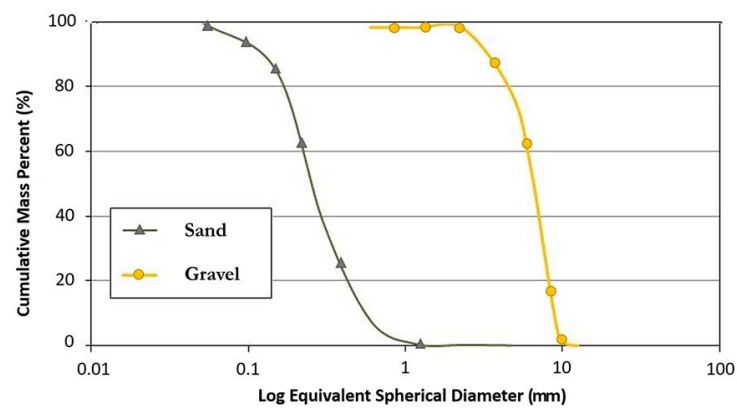

Figure 5. Particle size distribution of the sand and the coarse aggregate used.

\subsection{Corrosion potential}

The corrosion potential of the rebars exposed to semicycles of partial immersion in $3 \mathrm{wt} \% \mathrm{NaCl}$ solution for two days and semi-cycles of drying in a ventilated oven at $50^{\circ} \mathrm{C}$ for five days was verified after each semi-cycle. Figure 6 presents the results of the corrosion potential measurements.

In the first 63 days, the specimens were not subjected to wetting and drying cycles in $\mathrm{NaCl}$ solution until the "safe potential" was reached, and the tests were interrupted when the "unsafe potential" was reached in two consecutive dry state measurements. The values represent the average of four measurements taken for each composition. The error bars were not placed in graphs because they would make the graphs very confusing and difficult to visualize. However, the results were highly reproducible, with a variation of less than $6 \%$.

One of the aspects of the test procedure adopted is that the rebar corrosion potential varied throughout the test, showing more negative or more positive values depending on the semi-cycle to which the specimen was subjected. The most positive corrosion potential values were recorded after the drying cycles because, due to the decreasing amount of electrolyte, the concentration of dissolved substances increased. In fact, according to the Nernst equation, the equilibrium potential increases with the increase in activity, i.e., the increase in the effective concentrations of oxidized substances ${ }^{27,30}$. Studies by SANTOS ${ }^{18}$ and RIBEIRO et al. ${ }^{27}$ confirm this behaviour and show an inverse correlation between the corrosion potential and the moisture content of the concrete, indicating that an increase in moisture content implies a decrease in the measured rebar corrosion potential. 
In the salt spray exposure test, the parameters cited before (temperature, humidity, saturation level) are kept constant, causing a different behaviour in the corrosion potential measurements, as can be seen in Figure 7.

As suggested by GONZÁLEZ et al. ${ }^{32}$, the measures of the potential are not conclusive by themselves due to the variety of factors that affect it, they merely provide preliminary indicatives of the rebars corrosion situation. As can be seen, the corrosion potential of the coated rebars stayed in the uncertainty range $\left(\mathrm{E}_{\text {corr }}>-1.043 \mathrm{~V}\right.$, for rebars coated with Zinc and $\mathrm{E}_{\text {corr }}>-0.953 \mathrm{~V}$, for rebars coated with Zinc-Nickel), while the rebars with no coating presented potentials in the high corrosion probability range $\left(\mathrm{E}_{\text {corr }}<\right.$ $-0.274 \mathrm{~V})$. Such behaviour indicates that there is a protective effect on the reinforcing bars regarding their despassivation when they are coated with Zinc or the Zinc-Nickel alloy by electroplating process, which is due to the delay in the change from the passive to the active state of corrosion.

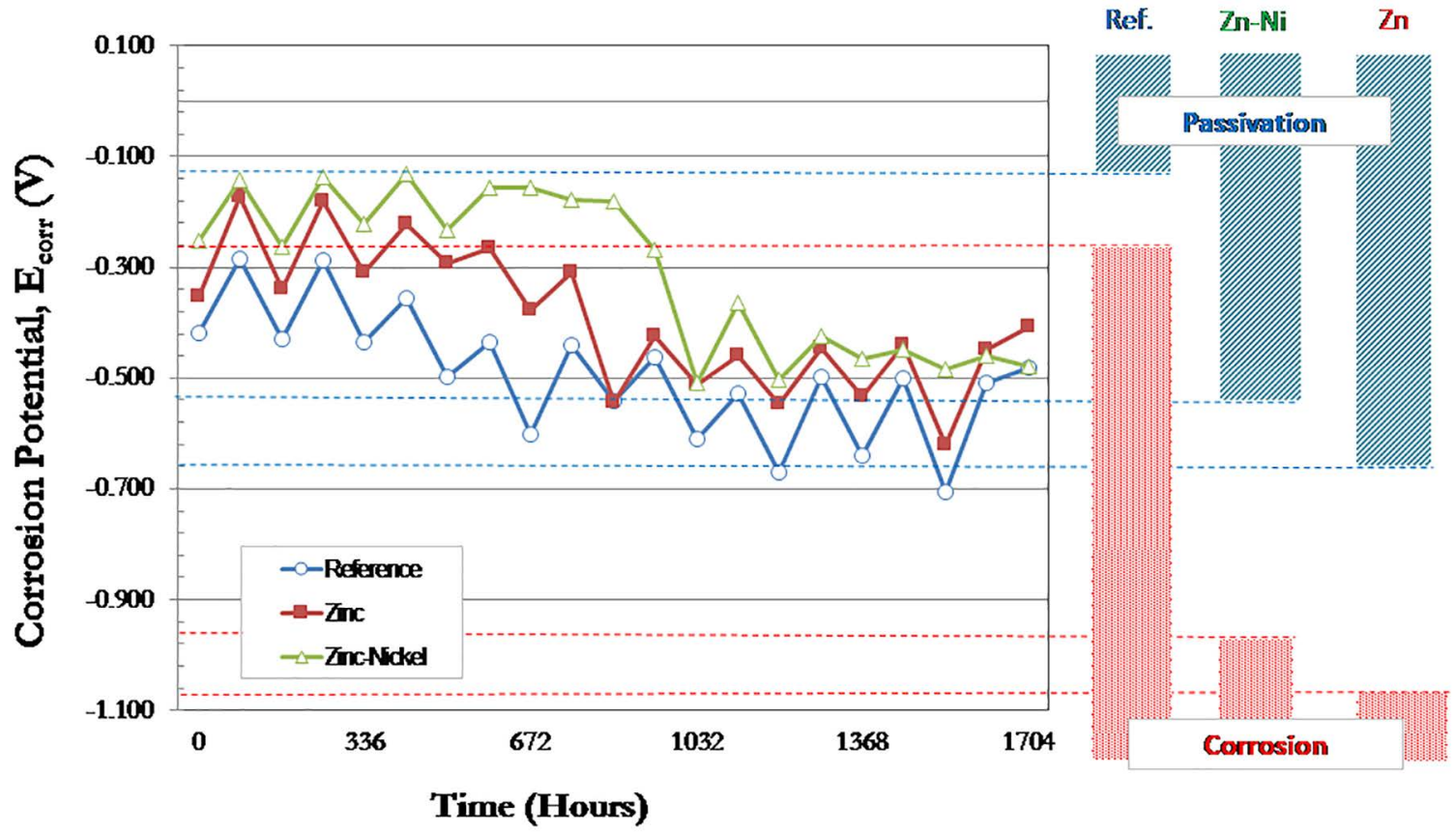

Figure 6. Evolution of the corrosion potential of reference and coated rebars exposed to semi-cycles of partial immersion in $3 \mathrm{wt} \% \mathrm{NaCl}$ and drying in a ventilated oven.

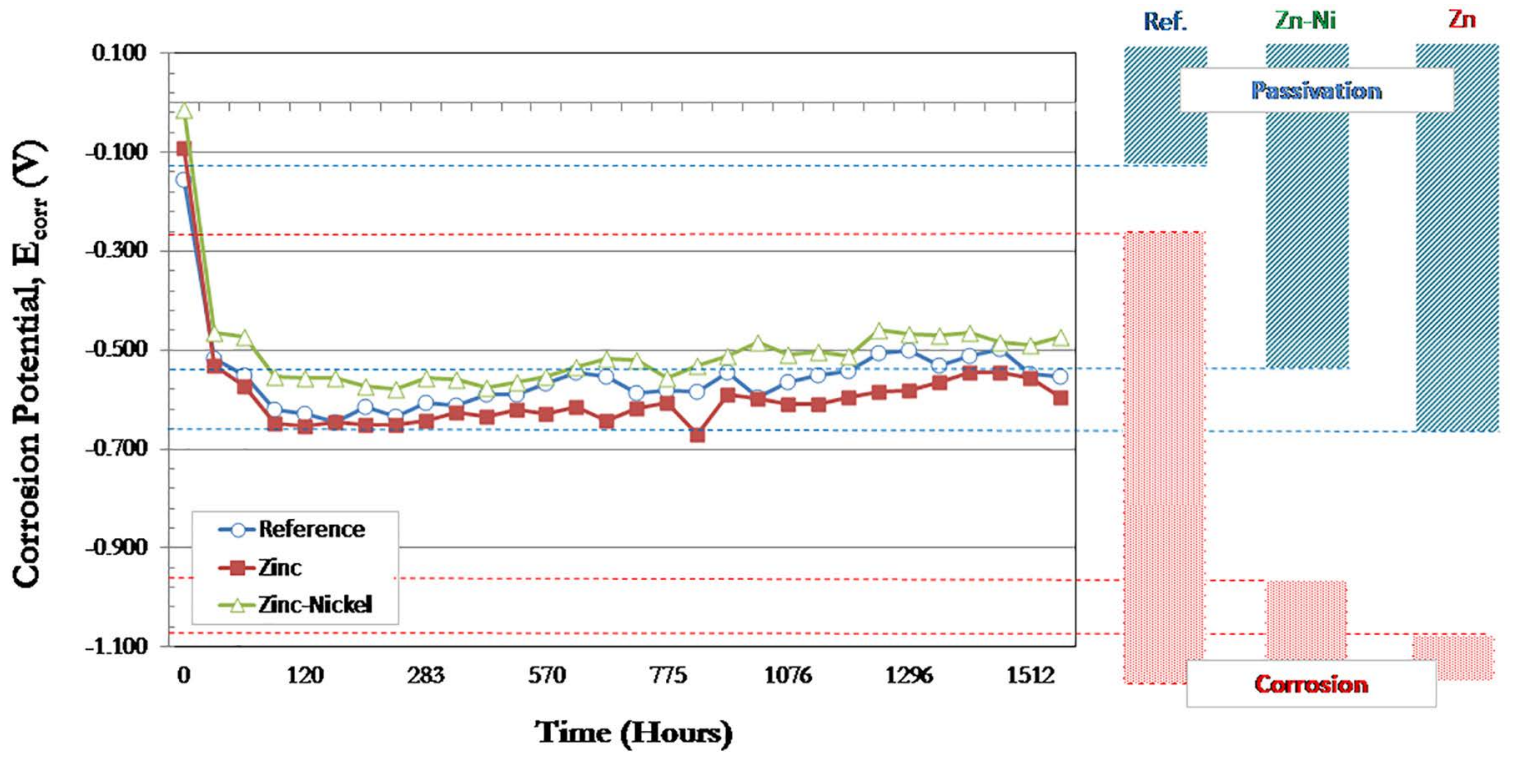

Figure 7. Evolution of the corrosion potential of reference and coated rebars exposed to salt spray. 


\subsection{Corrosion rate}

The corrosion rate, calculated from the loss of mass observed after accelerated corrosion tests for each group of rebars (coated with Zinc, Zinc-Nickel and uncoated), for specimens exposed to semi-cycles of partial immersion in $3 \mathrm{wt} \% \mathrm{NaCl}$ solution for two days and semi-cycles of drying in a ventilated oven at $50^{\circ} \mathrm{C}$ for five days and to salt spray, are presented in Figures 8 and 9, respectively. As expected, the galvanized reinforcement had a lower corrosion rate compared to the reference steel rebars.

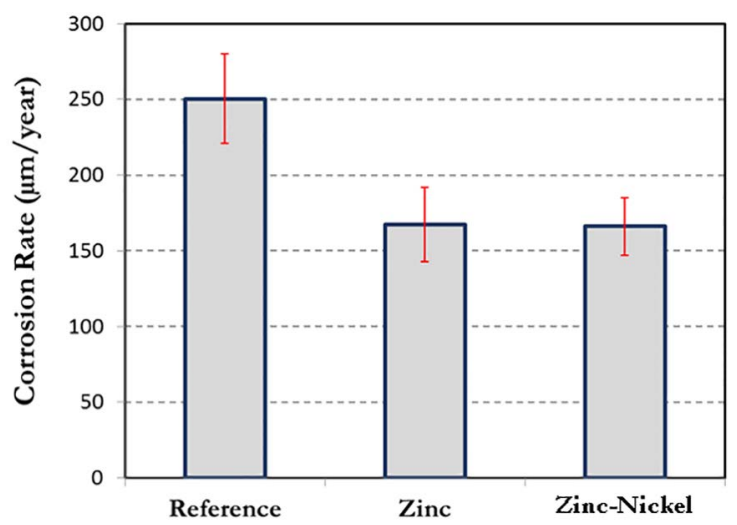

Figure 8. Corrosion rates of reference and coated rebars exposed to semi-cycles of partial immersion in $3 \mathrm{wt} \% \mathrm{NaCl}$ and drying in a ventilated oven.

The rebars that underwent the wet and dry cycles test, the reference rebars (uncoated) presented a corrosion rate ( $250.40 \mu \mathrm{m} /$ year) higher than those galvanized with Zinc (167.49 $\mu \mathrm{m} /$ year) and Zinc-Nickel $(166.15 \mu \mathrm{m} /$ year $)$, with a $33.1 \%$ and $33.6 \%$ decrease, respectively, if compared with reference rebars. It was also possible to note that the Zinc-Nickel coating presented higher durability (lower corrosion rate) due to the more uniform aspect of the zincnickel coating on the surface of the steel bar, according to SEM results. However, the decrease in the corrosion rate due to the presence of Ni was not significant due to the low $\mathrm{Ni}$ content in the deposit (8.17 wt.\%). The Ni content in the $\mathrm{Zn}$-Ni electrodeposits varies widely, with a Ni content up to 20 wt. $\%$.

The adopted thickness $(5 \mu \mathrm{m})$ of both coatings may have influenced the high deviation in the results, given that usual coating thicknesses are far greater (around $100 \mu \mathrm{m}$ ). It may also have contributed to the poor formation of the zinc oxides layer that would delay the corrosion process.

The lower rate of corrosion of the galvanized rebars in comparison with the bar without a coating in contact with the concrete is mainly attributed to the formation of calcium hydroxyzincate, $\mathrm{Ca}_{32}^{(\mathrm{Zn}(\mathrm{OH}))} \cdot 2 \mathrm{H}_{2} \mathrm{O}$, on the galvanized bar, according to equations 6 and 7 , which acts as a protective passive film ${ }^{33}$.
The formation of this compound occurs at a $\mathrm{pH}$ between 12.0 and $12.8^{34}$ and is associated with the humidity and calcium hydroxide present in the concrete.

$$
\begin{gathered}
\mathrm{Zn}+2 \mathrm{H}_{2} \mathrm{O} \leftrightarrow \mathrm{Zn}(\mathrm{OH})_{2}+\mathrm{H}_{2} \\
2 \mathrm{Zn}(\mathrm{OH})_{2}+-2 \mathrm{H}_{2} \mathrm{O}+ \\
\mathrm{Ca}(\mathrm{OH})_{2} \rightarrow \mathrm{Ca}\left[\mathrm{Zn}(\mathrm{OH}]_{3}\right)_{2} .2 \mathrm{H}_{2} \mathrm{O}
\end{gathered}
$$

One particular feature of these alkaline solutions, which is relevant for the behaviour of zinc, is that the concentration of $\mathrm{Ca}^{2+}$ ions decreases when the $\mathrm{pH}$ increases ${ }^{35}$. At a lower $\mathrm{pH}$, typical of the early stages of hydration, $\mathrm{Ca}^{2+}$ concentrations fall above of $\mathrm{Ca}^{2+}$ equilibrium, which indicates oversaturation in the solution. The presence of $\mathrm{Ca}^{2+}$ is needed for the passivation of zinc in alkaline solutions.

MACIAS and ANDRADE ${ }^{36}$ studied the stability of galvanized reinforcements in $\mathrm{NaOH}$ and $\mathrm{KOH}$ solutions in a $\mathrm{pH}$ range from 11 to 14 , both with and without the presence of $\mathrm{Ca}(\mathrm{OH})_{2}$. They found that, in a pH interval between 12 and $13.2+0.1$, the galvanized coating corrodes at an acceptably low rate. At a pH below 12, localized corrosion takes place while at a $\mathrm{pH}$ above to 13.2 , total dissolution of the coating occurs with no passivation.

The results obtained in the salt spray exposure tests (Figure 9) showed a lower variability and a difference of one order of magnitude, which indicates that this test is less aggressive than the wet and dry cycles test. The corrosion rate calculated was equal to $22.50 \mu \mathrm{m} /$ year for uncoated rebars, $15.58 \mu \mathrm{m} /$ year for zinc coated rebars, and $15.40 \mu \mathrm{m} /$ year for zinc-nickel coated rebars.

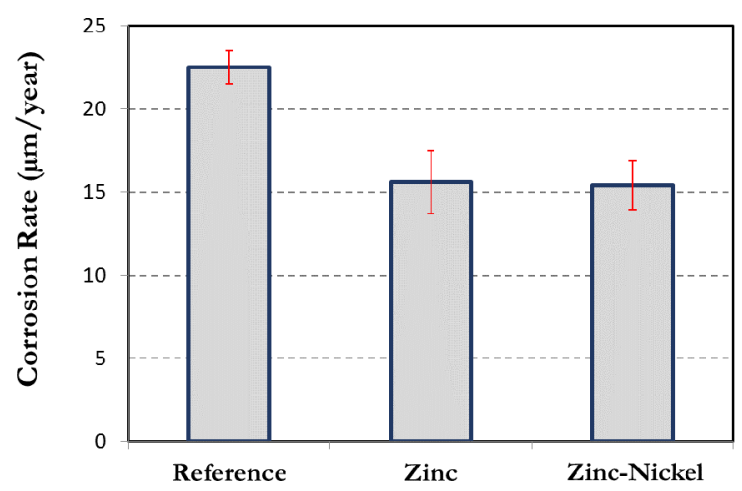

Figure 9. Corrosion rates of reference and coated rebars exposed to salt spray apparatus.

The "semi-cycle method" is more aggressive compared to the "salt spray method", which is demonstrated by the difference in the values obtained for the corrosion rate, which reach one order of magnitude (165 to $250 \mu \mathrm{m} /$ year versus 15 to $23 \mu \mathrm{m} /$ year), as verified in studies by Ribeiro ${ }^{4}$ and Ribeiro et al. ${ }^{27}$. 
This is because of capillary suction on the concretes submitted to wet and dry cycles that causes the concentration of chlorides inside the concrete to increase in comparison to the samples exposed to the salt spray.

\subsection{Steel-concrete adherence}

Figure 10 shows the results of the pull-out test. As expected, a reduction in the adhesion of the galvanized reinforcement in comparison to the reference reinforcement (without cover) was observed, due to the reduction in the height of the ribs. In addition, the chemical iteration between the zinc coatings and the hydrated calcium silicates of the cement may result in different ionic bonds. As a result, a reduction in bond stress of $16 \%$ was observed with the application of these treatments.

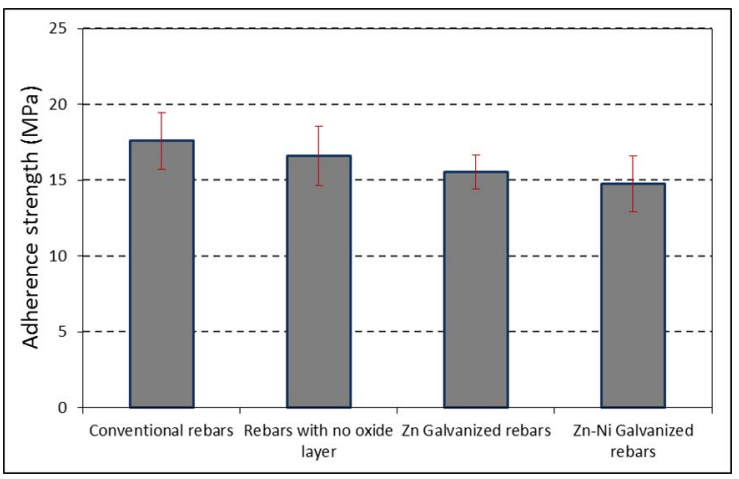

Figure 10. Pull out test resistance of rebars with different surface conditions.

Analyzing the flexural behaviour of reinforced concrete beams, Hamad and Mike ${ }^{37}$ identified a slight reduction in the tensile strength of beams with a galvanized bar compared to beams with black rebar due to a reduction in bond strength (4 to $6 \%$ ) due to galvanizing. Hamad and Jumaa ${ }^{38}$ suggest that a negative effect on the bond between the galvanized bar and the surrounding concrete can be associated to three factors: reduction in chemical adhesion and friction; passivation of galvanized bar due to the reaction which takes place between the zinc and the wet cement paste; the retarding effect of the corrosion products of the reaction of zinc with the wet cement paste on cement hydration.

Kayali and Yeomans ${ }^{24}$ compared the bond and slip behaviour of deformed (i.e. ribbed) galvanized and black steel rebars in concrete. These authors showed that the critical load verified for galvanized rebars was not statistically different to that verified for black steel. According to Pokorný et al ${ }^{39}$ the shear stress necessary to completely pull-out the hot-dip galvanized ribbed rebar from concrete is similar to that for black steel. However, the bond stress, for rebar displacement equal to $0.001 \mathrm{~mm}$, is smaller for electroplated rebars in comparison to conventional rebars without treatment, indicating a reduction in the adhesion bond with treatment.

\section{Conclusions}

From the results of the tests, it can be concluded that:

Galvanization by electroplating is a protective method which increases the corrosion resistance of rebars used in construction.

The Zinc and Zinc-Nickel coatings increased the durability of the reinforcing bars, although the thickness adopted in this research might not have been enough to promote a substantial increase in the life cycle, because this thickness might have interfered in the performance of the coatings.

The accelerated corrosion test of wetting and drying cycles proved to be more aggressive than the "salt spray method" in the evaluation of the corrosion process in the reinforced concrete specimens because of the capillary suction on the concretes submitted to wet and dry cycles that causes the concentration of chlorides inside the concrete to increase faster.

The use of more refined monitoring techniques is necessary to achieve a better understanding of how the coatings of zinc and zinc-nickel alloy work in reinforced concrete, as there is little in the literature about this.

The adherence loss due to the electrodeposition process is relatively small compared to the increase in the corrosion resistance of these reinforcements.

The adopted adherence test satisfactorily indicated a decrease in the concrete-steel bond for coated rebars which can be associated to the reduction in chemical adhesion.

\section{Acknowledgements}

CNPq - Brazilian National Council for Scientific and Technological Development.

CAPES - Coordination for the Improvement of Higher Education Personnel

FAPESB - Research Support Foundation of the State of Bahia

\section{References}

1. Koch GH, Brongers MPH, Thompson NG, Virmani YP, Payer JH. Corrosion Costs and Prevention Strategies in the United States. Report No. FHWA-RD-01-156. Washington, DC: Federal Highway Administration; 2002.

2. Koleva DA, Van Breu K. The integration of EIS parameters and bulk matrix characteristics in studying reinforced cementbased materials. Bulgarian Chemical Communications. 2012;44(4):324-332.

3. Gentil V. Corrosão. 5a ed. Rio de Janeiro: LTC; 2007.

4. Ribeiro DV, coord. Corrosão e degradação em estruturas de concreto armado: Teoria, controle e métodos de análise e intervenção. Rio de Janeiro: Elsevier; 2018. 
5. Thériault M, Benmokrane B. Effects of FRP Reinforcement Ratio and Concrete Strength on Flexural Behavior of Concrete Beams. Journal of Composites for Construction. 1998;2(1):7-16.

6. Langill TJ, Dugan B. Zinc Materials for Use in Concrete. In: Yeomans SR, ed. Galvanized Steel Reinforcement in Concrete. Chapter 4. Amsterdam: Elsevier Science; 2004. p. 87-109. DOI: https://doi.org/10.1016/B978-0080445113/50019-0

7. Swamy R.N. Design for Durability with Galvanized Reinforcement. In: Yeomans SR, ed. Design for Durability with Galvanized Reinforcement. Chapter 2. Amsterdam: Elsevier Science; 2004. p. 31-69. DOI: https://doi.org/10.1016/B978008044511-3/50017-7

8. Yeomans SR. Galvanized Steel in Concrete: An Overview. In: Yeomans SR, ed. Galvanized Steel Reinforcement in Concrete. Chapter 1.Amsterdam: Elsevier Science; 2004. p. 1-30. DOI: https:// doi.org/10.1016/B978-008044511-3/50016-5

9. Yeomans SR. Performance of Black, Galvanized, and EpoxyCoated Reinforcing Steel in Chloride-Contaminated Concrete. Corrosion. 1994;50(1):72-81.

10. Broomfield JP. Galvanized Steel Reinforcement in Concrete: A Consultant' Perspective. In: Yeomans SR, ed. Galvanized Steel Reinforcement in Concrete. Chapter 9. Amsterdam: Elsevier Science; 2004. p. 271-285. DOI: https://doi.org/10.1016/B978008044511-3/50025-6

11. Yeomans SR. Laboratory and Field Performance of Galvanized Steel in Concrete. In: Yeomans SR, ed. Galvanized Steel Reinforcement in Concrete. Chapter 6. Amsterdam: Elsevier Science; 2004. p. 145-197. DOI: https://doi.org/10.1016/B978008044511-3/50021-9

12. Gravila M, Millet JP, Mazille H, Marchandise D, Cuntz JM. Corrosion behaviour of zinc-nickel coatings, electrodeposited on steel. Surface and Coatings Technology. 1999;123(2-3):164172 .

13. Ghaziof S, Gao W. Electrodeposition of single gamma phased $\mathrm{Zn}-\mathrm{Ni}$ alloy coatings from additive-free acidic bath. Applied Surface Science. 2014;311:635-642.

14. Wilcox GD, Gabe DR. Electrodeposited zinc alloy coatings. Corrosion Science. 1993;35(5-8):1251-1258.

15. Jesus MD. Efeito do glicerol como aditivo para resistência à corrosão do revestimento de zinco obtido através de eletrodeposição. [Master thesis]. Salvador: Federal University of Bahia (UFBA); 2009. 112 p. (in Portuguese)

16. Zempulski LN, Zempulski MFS. Dossiê técnico: galvanização eletrolítica. Curitiba: Instituto de Tecnologia do Paraná (TECPAR); 2007. $21 \mathrm{p}$.

17. Freire KRR. Avaliação do desempenho de inibidores de corrosão em armaduras de concreto. [Master thesis]. Curitiba: Federal University of Paraná (UFPR); 2005. 132 p. (in Portuguese)

18. Sherine HB, Rajakumari CC, Rajendran S. Corrosion Behaviour of Stainless Steel 304 Electroplated with Zinc Followed by Blue Passivation. Portugalia e Electrochimica Acta. 2011;29(4):295-305.
19. Panek J, Bierska-Piech B, Karolus M. The corrosion resistance of zinc-nickel composite coatings. Journal of Achievements in Materials and Manufacturing Engineering. 2011;45(2):157-162.

20. Chu SH, Kwan AKH. A new method for pull out test of reinforcing bars in plain and fibre reinforced concrete. Engineering Structures. 2018;164:82-91.

21. Kim JK, Mai YW, eds. Engineered Interfaces in Fiber Reinforced Composites. Oxford: Elsevier Science; 1998.

22. Caetano LF. Study of the bonding behavior of reinforced concrete elements subjected to extreme conditions. [Master thesis]. Porto Alegre: Federal University of Rio Grande do Sul (UFRS); 2008. 178 p. (in Portuguese)

23. Cheng A, Huang R, Wu JK, Chen CH. Effect of rebar coating on corrosion resistance and bond strength of reinforced concrete. Construction and Buildings Materials. 2005;19(5):404-412.

24. Kayali O, Yeomans SR. Bond of ribbed galvanized reinforcing steel in concrete. Cement and Concrete Composites. 2000;22(6):459467.

25. Soares ME, Souza CAC, Kuri SE. Corrosion resistance of a $\mathrm{Zn}-\mathrm{Ni}$ electrodeposited alloy obtained with a controlled electrolyte flow and gelatin additive. Surface and Coatings Technology. 2006;201(6):2953-2959.

26. Ramanauskas R, Quintana P, Maldonado L, Pomés R, Pech-Canul MA. Corrosion resistance and microstructure of electrodeposited $\mathrm{Zn}$ and $\mathrm{Zn}$ alloy coatings. Surface and Coatings Technology. 1997;92(1-2):16-21.

27. Ribeiro DV, Labrincha JA, Morelli MR. Effect of the addition of red mud on the corrosion parameters of reinforced concrete. Cement and Concrete Research. 2012;42(1):124-133.

28. Santos L. Evaluation of the electrical resistivity of concrete as a parameter to calculation of the initiation period of corrosion induced by chlorides in concrete structures. [Master thesis]. Brasília: University of Brasília (UNB); 2006. 161 p. (in Portuguese).

29. Bauer E. Avaliação comparativa da influência da adição de escória de alto forno na corrosão das armaduras através de técnicas eletroquímicas. [PhD thesis]. São Paulo: University of São Paulo (USP); 1995. 236 p. (in Portuguese).

30. Rocha FC. Leituras de potencial de corrosão em estruturas de concreto armado: influência da relação água/cimento, da temperatura, da contaminação por cloretos, da espessura de cobrimento e do teor de umidade do concreto. [Master thesis]. Curitiba: Federal University of Paraná (UFPR); 2012. 132 p. (in Portuguese).

31. Comité Euro-International du Béton/RILEM/CEB/FIP. Recommendation RC6. Bond test for reinforcing steel: Pullout test. Concrete Reinforcement Technology. Paris: Georgi Publishing; 1983.

32. González JA, Miranda JM, Feliu S. Considerations on reproducibility of potential and corrosion rate measurements in reinforced concrete. Corrosion Science. 2004;46(10):2467-2485.

33. Macias A, Andrade C. The behavior of galvanized steel in chloride-containing alkaline-solutions-I. The influence of the cation. Corrosion Science. 1990;30(4-5):393-407.

34. Belleze T, Malavolta M, QuarantaA, Rufini N, Roventi G. Corrosion behaviour in concrete of three differently galvanized steel bars. Cement and Concrete Composites. 2006;28(3):246-255. 
35. Moragues A, Macias A, Andrade C. Equilibria of the chemical composition of the concrete pore solution. Part 1: Comparative study of synthetic and extracted solutions. Cement and Concrete Research. 1987;17(2):173-182.

36. Andrade C, Alonso C. Electrochemical Aspects of Galvanized Reinforcement Corrosion. In: Yeomans SR, ed. Galvanized Steel Reinforcement in Concrete. Chapter 5. Amsterdam: Elsevier Science; 2004. p. 111-144. DOI: https://doi.org/10.1016/B978008044511-3/50020-7.
37. Hammad BS, Mike JA. Bond strength of hot-dip galvanized reinforcement in normal strength concrete structures. Construction and Building Materials. 2005;19(4):275-283.

38. Hamad BS, Jumaa GK. Bond strength of hot-dip galvanized hooked bars in high strength concrete structures. Construction and Building Materials. 2008;22(10):2042-2052.

39. Pokorný P, Dobiáš D, Vokáč M. Bond strength of hot - dip galvanized reinforcement (B500B) with concrete. Metalurgija. 2016;55(3):337-340. 